\title{
Value Orientation of School Physical Education Reform From the Perspective of Life Outlook
}

\author{
Chenliang Deng ${ }^{1}{ }^{*}$, Qiaoyan $\mathrm{Yu}^{2}$
}

\author{
${ }^{I}$ Sports Department, University of Electronic Science and Technology of China, Chengdu, China \\ ${ }^{2}$ Gymnastics College, Chengdu Sports University, Chengdu, China \\ *Corresponding author. Email: 850620188@qq.com
}

\begin{abstract}
This paper uses the methods of literature and logic analysis to exemplify on the necessity to speed up construction of China into a country strong in physical education and reestablish a development orientation for school physical education in the new era. It puts forward the inevitability to develop school physical education in China based on the orientation of life education by following the trend of the times to recover the nature of education and the essence of physical education. With life education as the orientation, the paper believes it a serious theoretical issue as well as a common practice issue to reinterpret the nature of physical education, resummarize the functions of physical education, reevaluate and reelucidate the value and significance of physical education, reconsider the reform on school physical education, provide new content system and method system for development of school physical education in the new era, and rectify the one-sided understanding on the nature, functions, and roles of physical education, and thus changing the misleading outlook of traditional physical education which is indifferent to and trampling on life.

Keywords: Life education, school physical education, life-oriented reform, value orientation
\end{abstract}

\section{INTRODUCTION}

Given the special background of China under rejuvenation, we may have found that the development of physical education for schools and for teenagers in China has been limited by the over narrow-mindedness and one-sidedness in value orientation, and full of utilitarianism that has dragged school physical education away from the life purpose, weakened the importance of life purpose in social sports education, and even maltreated lives in athletics sports, which has led to a sharp contrast between weak physical quality of teenagers and the glorious achievements in athletic sports in China. Since the People's Republic of China was founded, in order to quickly delete the national image of "Sick men of East Asia" and improve China's international position to a higher level, China has adopted the "nation-wide system" for the undertaking of physical education and seeking accelerated development for "swifter, higher, and stronger" athletic sports. In order to ensure effective operation of the "nation-wide system", school physical education in China positively or passively take athletic sports as the orientation, and making it part of "three-level training system" of Chinese characteristics, which "leads many teenagers to become backup talents", and "school physical education to become the cradle for training world champions".

For the historical merits and faults of developing school physical education based on orientation of athletic sports, objective reviews and calm analysis should be conducted.
Nonetheless, there is undoubtedly one point: driven by the "gold medal strategy" and in the practice with over emphasis on the "technique priority", essence and functions of physical education have increasingly been instrumentalized. While developing school physical education, meaning of human life has gradually been ignored, and the value of human life has gradually been lost, which not only results in many scholars' thinking over the essence and functions of physical education, but also invokes high attention from the Communist Party of China and the Central Government on the problems existing in development of school physical education.

Reestablishing life education as the development orientation for school physical education in the new era, making right the one-sidedness of understanding on the essence, functions, and roles of physical education, and reverting the wrong awareness of traditional physical education which is careless and harsh to life, is a serious theoretical concern as well as a common practical problem.

\section{VALUE ORIENTATION OF LIFE- ORIENTED REFORM FOR SCHOOL PHYSICAL EDUCATION}

\subsection{Promotion of a Healthy Life as the Logical Starting Point for School Physical Education}

G. W. F. Hegel believed that logical starting point is actually a question of "what must be applied as a scientific 
beginning" [1], and a fundamental question regarding the theoretical category of a discipline. Scientific determination of a logical starting point marks the scientific degree of the discipline, indicates the degree of maturity and completeness of the discipline, and leads the right direction of development for the discipline. At the time when physical education of modern schools enters knowledge economy, Internet economy, and science and technology based information times, people are feasting on the prosperity of material civilization while faced with the threat from damaged ecological environment. Human beings are swallowing down the evil consequence of degeneration of their own biological structure and physical functions, and are confronted with spreading and outburst of diseases of affluence and severe perplex of such sub-healthy problems as various kinds of psychological disorders and diseases, etc.

School physical education must stand itself out from relative problems and perplex, and examine on the basic question of what to teach and how to teach for school physical education based on the logical starting point to promote development of life health for students. To follow the life health orientation, school physical education should teach preliminary knowledge of structures and functions of the body system for students to have basic understanding and skills of physical exercise, teach students the method and skills for maintaining health and development of the body and how to improve strength, speed, sensitivity, endurance, and flexibility of the body; guide students to learn and grasp knowledge of physical education and health, master the method for enhancing physical quality, and regulate their own health conditions, and understand the the capital value and cost input for maintaining physical health; cultivate the students' interest in physical exercise, and form their habit to actively participate in physical activities and their awareness to do physical exercise regularly; enable students to learn to change physiological and psychological cycle, learn about aesthetic knowledge and skills, and foster the sentiment for life, and establish the students' habit to maintain hygiene and health care, help the students to learn the knowledge and method for maintaining health of the brain; guide students to pay attention to coordinated development of mind and body; strengthen management on students' health archives and provide lifelong tracking and monitoring on the students' status of life; collect information about the students' physical health conditions so that PE courses and teaching work may be better regulated, and the students may compare with the indicators obtained through the monitoring and get to know what further efforts need to be made to reach the state of healthy life[2].

By learning about these knowledge and skills, mastery of body-building methods, active transmission of ideologies, and tracking of health conditions and life quality, school physical education can facilitate energy of human body, and improve or maintain the vitality of the body. Such functions and values are irreplaceable by any other activities of human race.

\subsection{Inspiration of Spiritual Life as the Value Pursuit of School Physical Education}

Every living entity demonstrates its life activities in its own unique way; therefore it's different from the existence mode of other living things. Transcendence means the life embodies richer and more concrete prescription and peculiarity [2]. Man's essential attribute is the unity of spirituality and sociality, and physical exercise is a transcendence of unlimited spirit against limited life span. In physical exercise, especially when facing the motion limit of man's physical functions, man's life accomplishes a transcendence over natural life under active participation of various kinds of systems, organs, tissues and cells, and lifts the life up to the spiritual phase. The value and meaning of life is more than often spiritual oriented, and is often represented by pursuing life value and self-fulfillment. It's just under guidance of spirit that life gradually gets rid of the constraint from its material carrier. Spiritual life is the higher form of human life that gives spirituality to people, and should be the value to be pursued by school physical education in the contemporary era. "Medicine can cure a man's physical illness, but it provides no remedy against one's barren spiritual world and fragile soul." In the face of all kinds of misdeeds of teenage students, it's surprising that the exclusive spiritual "nutrient" contained in school physical education hasn't been "injected", "digested and assimilated", so that school physical education has basically been drifted away from the essence of physical education, and affected by some superficial and vague notions, and has thus neglected the role of spirit outreaching in the course of reform on man's natural life [3].

Such "rich nutrients" as unyieldingness on difficulties, undauntedness against repeated setbacks, striving for progress, unity and cooperation, bravery to challenge new height, etc. have nearly been lost all in school physical education, the result of which is student's independent living ability, volitive quality and adaptability have become worse and worse, and the spiritual wealth of physical education has turned from bad to worse. Therefore, research on school physical education absolutely should not be lack of the peculiarity of spiritual phase. During the course of reform on man's natural life by school physical education, attention should be paid to cultivation of such non-intelligent factors as combatant spirit, volitional quality, independent personality, etc, so that the students may build up a self-awareness to pursue self-value and spiritual outreach. "Looking at the dynamic and extensive physical education with a static and partial vision, physical education will simply be reduced a low biological level. And if we look at physical education as a collection of teaching rules, or as a sport therapy prescribed as per diseases, it would hardly be acceptable by humanistic concept of physical education."[4] School physical education is the best method of education to cultivate character of life, train on will of life, and transcend oneself. It coincides with the spiritual life of "swifter, higher, and stronger" pursued by the Olympic 
Games, which are also one of the important dimensions of school physical education.

However, modern school physical education mixes up the difference and relation between feeling and experience, and pays attention to experience while neglecting feeling, and deviates from the fundamental understanding that physical education is a process of feeling for life, which fail the students to enjoy the indispensable and unique perception and feeling in the course of growth. In school education, only physical education can satisfy students need to feel and perceive on the real essence of life during the course of growth. The spirits such as progressive spirit, combatant spirit, striving spirit, adventurous spirit, innovation spirit, fair competition and team work spirit, etc., that are manifested when students are taking physical exercise, are exclusively embodiment of wonderful spirits of life; the consciousness, decisiveness, tenacity, self-control ability, transcendence, etc., the students cultivate in physical exercise are all miniatures of positive spiritual and volitional qualities; in the course of physical exercise, students may experience "torture on the will, toil on the bones and muscles, starvation of the stomach, emptiness of the body, and intentional or unintentional disturbances", feel joys, sufferings, setbacks, challenges, passion, and transcendence, etc of life process, and experience the feelings of life such as harmony and competition, success and failure, growth and recession of human beings, nature, and society. These are all the essential facts of life. Hence, physical exercise stimulates the passion of life, opens up the inspiration of life, provides fun of life, gives enjoyment of life process, displays personality of individual life, motivates emotion of life, and sets off the spirit of life.

\subsection{Improvement of Life Quality as Functional Pursuit for School Physical Education}

Quality of human life is not only shown in the physical value of individuals, it is also embodied in the spiritual (mental) and social values. It's impossible for us to talk about improvement of spiritual and social values separately from existence of human physical body. Improvement of life quality is the sum of the three aspects, any of which cannot go without the other two, and must seek overall development in coordination with the other two aspects. School physical education bears unique functions in improving quality of life, and is more beneficial to overall coordinated development of human being. Obviously, school physical education has a fundamental function for body building, which is mainly shown in the its ability to improve brain's working capacity, promote growth of physical organs, strengthen functions of human body, regulate man's psychology, and enhance adaptability of human body, etc. Also, school physical education contains general functions of multiple dimensions, such as the functions to civilize and educate, to promote socialization of individuals, to deliver aesthetic values, and to facilitate overall development of individuality of the students, etc. These two types of functions of school physical education are a transition from the traditional single biological view to multi-dimensional life-based view, and indicate that functions of school physical education should be comprehended omnibearingly from different levels, not only from the biological level, but also from education, society, psychology, and other perspectives. School physical education is an important part of school education. It is closely combined with moral education and intelligence education, and undertakes the historic mission to produce talents with all-round development in morality, intelligence, and physical soundness for the society. Besides, school physical education is the key for national body-building campaign, the basis for lifelong physical education and athletic sports, and is the critical section for development of the cause of physical education in China.

But, our country has part of the principal, head teacher, teachers, students, parents, and quite a number of different levels of people at all levels of society, the cognition and understanding of school sports in a what level? Where do you put school sports in education? Many schools, parents, teachers and students are under pressure to learn and obtain employment, and have not yet shaken off the influence of traditional old ideas on the mind, so they have played down or ignored the function of school sports. Of course, every sports worker, must be the orientation of sports education, goal, idea, method, process problems for deep thoughts, really dig in school physical education and health education on life education unique utility. As the product of human social development, school sports is the carrier of human development to improve the quality of life. Sports function is based on the body of the people's health and mental health needs, through physical education to deliver moral ideology, political attitude, health knowledge, spirit concept, core value, and uphold human unity and political stability, reveal the life value and improve the quality of life. Today the school too much emphasis on the students' subjectivity education reform, indefinitely respect individuality, ignoring the function of school physical education, weakening the will of life, is the indifference and weakening of sports function particularity, which may lead to education reform in the wrong direction and the lack of education function. From a philosophical point of view, school sports is both an epistemology and a practical form of science and technology, as well as a practical form of ontological and humanistic dimensions. Therefore, in the sports activities, the students' spirit, emotion and so on have the effect that cannot ignore.

School sports is an integral part of social culture, and it will also produce more important social functions when it has a very harmonious and effective connection with various fields of society. Therefore, the school sports system interacts with other systems of society, and shows itself relatively special in the role and efficiency of people and society. This kind of joint action and efficiency continuously enhances the student individual and the whole life quality, and also acts together with the society. It can be seen that the quality of life reflects a relationship 
between the real person and the attributes of the object that satisfies some of its needs. In this sense, the function of school sports is given by people, which is based on "the inner scale of human beings", which reflects the direction and purpose of human sports practice. People through sports practice gradually understanding physical properties, and use these properties to meet their needs, make sports are beneficial to the people of the ways to improve the quality of life of people by people in the form of possession.

\subsection{Moulding of Social Life as the Pursuit of Significance for School Physical Education}

Physical body is no longer purely a natural being, no longer purely an organic body, no longer an object of medicine, biology, and anthropology, and no longer a pure tool of labor and production. Now, the surface of the body is no longer just smooth skin, strong and well-built muscles, and solid skeletons, it has carried more complicated social imprints. As described in "Political Bodies", "body itself is the purpose" [5]. Life is a social existence. If life is seen only as a material, then the significance of life will be far under-estimated, and the value of life will have been demeaned, and human life is then mixed up with that of animals, and stands no essential difference from the life of animals. If we look at the spiritual life of human being only, it would be very easy to leave the fresh flower of human life to gradually go withered in narrow fields, because in that way, life would be regarded as an isolated existence with its internal and spiritual connection with other individual social beings cut off. Emergence of school physical education is the result of the need for social development, and bears strong social attributes. In terms of time and space, school physical education preserves and inherits specific social cultures, and at the same time is limited by given political and economic need of the country [6].

Reviewing the development course of school physical education of China in over 100 years of time, it's not difficult to find that: development of school physical education was affected by "society-centered theory", "children-centered theory", and "knowledge-centered theory". In terms of social attributes, school physical education has often been positioned as of educational or political attributes, and the social attributes of physical education is categorized as part of superstructure, which neglects the cultivation of social adaptive qualities such as responsibility, cooperation, volition, and emotions, etc. It's no wonder that physical "sport professionals" are often regarded as culturally illiterate "with simple mind and well-developed limbs". Therefore, underestimation of the social value of school physical education has also resulted in relative lagging-behind of researches on school physical education and misunderstandings of social values of school physical education. This is more worrisome to people, in that it weakens and neglects the multi-dimensional attributes of school physical education. In this case, students are often unconscious of external physical body and internal spirits, and are obviously lack of volitional qualities and the spirit to strive for progress against hardships, with decadent, suicidal and self-abuse psychology, and without social sense of responsibility and social emotions, etc. Therefore, social value of school physical education does not statically exist in the connection between the subject and the object. It is not affected simply by education and politics, but it is generated in the active practice of physical exercise of the subject. Students can only realize the actual significance of the physical activities for themselves through practice of physical education, understand the social attributes of social value of physical education, and utilize these attributes to satisfy their own social needs, thus physical education activities may be carried out by people in a way benefiting people and satisfying people's needs, e.g. the social values of striving, entertainment, social communication, fair, competition, collaboration, etc of school physical education.

Society is an existence form of human lives. School physical education should shoulder the social mission to cultivate students' awareness of competition and cooperation, spirit of teamwork, and the habits of formal and honesty behaviors, and establish in them concepts of fairness and justice as well as the sense of social responsibilities [7]. Only when man learns to cooperate, forms good moral habits, and commits to take social responsibilities and obligations can the value and meaning of his life be sublimed.

\section{SUMMARY}

Whatever the developmental tendency of school physical education in the future, one thing is for sure is that life education must be a school sports rights and obligations, will necessarily throughout all aspects of the lifelong sports, all kinds of range. School sports education only adopts the thought of life education to become an effective, just and humane cause. Therefore, school sports will also become a lifelong career, throughout the entire life cycle [8]. Only make the school physical education based on student's lifelong development and focus on students' life development, and based on this, will make effective penetration and join the school physical education and school education, can we truly achieve the individual ultimate concern for life.

\section{ACKNOWLEDGMENT}

This research was financially supported by UESTC Higher Education Talent Training Quality and Teaching Reform Project (2016-2018) under Grant No. 2016XJYYB058. 


\section{REFERENCES}

[1] G. W. F. Hegel, Translated by Y. Z. Yang, Logic (Part I), Commercial Press, Beijing, 1982.

[2] J. P. He, Exploration on the Life of School Physical Education Curriculum System, Ph.D., Northeast Normal University, China, 2008.

[3] Z. G. Yuan, New Concept of Education, Educational Science Publishing House, Beijing, 2001.

[4] Y. Z. Lu, An Outline Course of Humanistic Social Science for Physical Education, Higher Education Press, Beijing, 2003

[5] H. B. Ge, G. Song, Body Politics, Shanghai Joint Publishing Press, Shanghai, 2005.

[6] Y. L. Shao, S. S. Shi, Y. Y. Gu, Introduction to Physical Education, Peoples Sports Publishing House, Beijing, 2005.

[7] X. R. Liu, J. Wang, The Mission of School Physical Education in the New Era -- Based on the Spirit of the Report of the 19th National Congress of the Communist Party of China, J. Beijing Sport Univ. 42 (2019) 1-12.

[8] L. M. Duan, G. B. Dai, A New Theory on the Logical Starting Point of Physical Education from the Perspective of Whole Person Life Education, China Sport Sci. 35 (2015) 78-82. 